\title{
PENERAPAN ENTERPRISE RESOURSE PLANNING PENJUALAN AKSESORIS BERBASIS ODOO
}

\author{
Suminten $^{1}$, Silvy Amelia ${ }^{2}$, Ita Dewi Sintawati ${ }^{3}$ \\ ${ }^{I}$ Prodi Sistem Informasi Fakultas Teknologi Informasi, Universitas Bina Sarana Informatika PSDKU Bogor, \\ ${ }^{1}$ Jln. Raya Media No.168, Ciwaringin, Ciwaringin, Bogor, Jawa Barat \\ ${ }^{2,3}$ Prodi Sistem Informasi Fakultas Teknologi Informasi, Universitas Bina Sarana Informatika Jakarta \\ ${ }^{2,3}$ Jl. Kamal Raya No.18,Ringroad. Cengkareng, Jakarta Barat

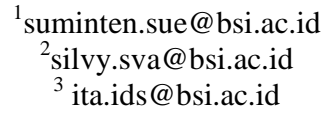

\begin{abstract}
Abstrak- Odoo merupakan aplikasi open source berbasis web digunakan sebagai aplikasi Sistem Informasi Miniso, untuk menyesaikan permasalahan dalam pengelolaan transaksi bisnis . Aplikasi Odoo sangat tepat untuk menyelesaikan permasalahan pengelolaan transaksi bisnis Miniso yang masih manual. Sistem ERP ini tidak hanya dapat menggunakan jaringan intranet saja akan tetapi jaringanya sudah bisa terkoneksi internet sehingga memudahkan bagi user untuk melakukan penginputan data, pengolahan, dan pembuatan ouput yang berupa laporan dapat dilakukan secara online. Modul-modul yang disediakan oleh Odoo sendiri banyak, antara lain: accounting, inventory, sales, purchase, point of sales, CRM, website, Human Resources, E-commerce, Project Management dan masih banyak lagi. Pengguna hanya tinggal meng-install modul-modul yang dibutuhkan. Modul yang tersedia adalah standar sistem internasional. Pada penelitian ini, penulis mencoba mengimplementasikan Odoo ini pada system data di Miniso. Dimana terdapat 14 tampilan yang dibuat, antara lain menu login sebagai menu awal untuk masuk ke system ini, menu warehouse untuk menampilkan stok barang pada gudang, sampai yang terakhir adalah menu laporan. Dengan dibuatkannya aplikasi ini diharapkan dapat mempermudah pengguna terutama admin dalam mengelola proses transaksi bisnis di Miniso, yang mencakup antara lain laporan permintaan dan stok barang, laporan order barang, sampai dengan laporan akhir.
\end{abstract}

Kata kunci : odoo, ERP, implementasi , modul, open source, berbasis web.

\section{PENDAHULUAN}

Sistem ERP (Enterprise Resouce Planning) menjadi salah satu solusi bagi perusahaan dengan bisnis yang kompleksitasnya tinggi. Sistem ERP merupakan sebuah sistem yang mendukung proses bisnis dengan menyediakan informasi secara realtime yang terintegrasi antar divisi - divisi fungsional perusahaan. Dengan adanya ERP, perusahaan dapat memanipulasi data atau informasi dalam jumlah yang besar untuk diolah dan ditampilkan sesuai dengan yang diinginkan.

Saat ini sudah banyak sistem ERP yang telah dikembangkan oleh para vendor software, antara lain, Microsoft Dynamic, Oracle, Odoo, dan SAP. Sistem ERP bukanlah hal yang asing lagi dan bahkan telah menjadi salah satu hal krusial yang harus dimiliki oleh perusahaan untuk mengintegrasi segala bagian serta proses kegiatan bisnis dalam perusahaan. Namun pada prakteknya di Indonesia, tidak semua perusahaan menggunakan sistem ERP karena biaya yang cukup tinggi serta kompleksitas yang rumit.

Adanya faktor - faktor tersebut akhirnya membuat perusahaan menengah kebawah memutuskan bahwa mereka belum mampu menggunakan sistem ERP.[1]

Memang benar bahwa implementasi sistem ERP selalu terkesan mahal, namun jika diteliti dengan lebih jeli, sebenarnya sudah banyak vendor - vendor yang menawarkan solusi untuk permasalahan di atas. Salah satu solusi untuk mengatasi permasalahan tersebut adalah dengan sistem ERP yang bersifat open source, salah satunya ialah OpenERP atau Odoo ( nama baru dari OpenERP).[2] 
OpenERP adalah sebuah sistem manajemen yang menyediakan lebih dari 4000 aplikasi untuk menunjang kebutuhan bisnis perusahaan. Saat ini, OpenERP telah tersedia dalam 18 bahasa dan memiliki partner serta contributor dari seluruh dunia. Lebih dari 1500 developer telah berpartisipasi dalam proyek pengembangan sistem Open ERP.[3]

Odoo merupakan aplikasi open source berbasis web digunakan sebagai aplikasi Sistem Informasi Miniso, untuk menyesaikan permasalahan dalam pengelolaan transaksi bisnis. Aplikasi Odoo sangat tepat untuk menyelesaikan permasalahan pengelolaan transaksi bisnis Miniso yang masih manual. Sistem ERP ini tidak hanya dapat menggunakan jaringan intranet saja akan tetapi jaringanya sudah bisa terkoneksi internet sehingga memudahkan bagi user untuk melakukan penginputan data, pengolahan, dan pembuatan ouput yang berupa laporan dapat dilakukan secara online.

Kecepatan dan ketepatan input data di dalam sistem sudah baik, sehingga menghasilkan informasi yang berkualitas. Kurang terjalinnya komunikasi yang baik antara user sehingga sering mengalami keterlambatan input data.[4]

Tujuan dari penelitian ini adalah untuk mengetahui, menganalisis, mendeskripsikan implementasi sistem ERP (Enterprise Resource Planning) untuk pengolahan transaksi bisnis Miniso.

\section{METODE PENELITIAN}

\section{A. Identifikasi Masalah}

Tahapan ini, permasalahan-permasalahan sistem yang terjadi pada Miniso diidentifikasi berdasarkan keilmuan Sistem Informasi. Berdasarkan indentifikasi masalah sistem yang masih manual dan belum terkafer dengan baik sehingga perlu dilakukan konversi sistem lama ke sistem yang baru, permasalahan yang diteliti yaitu proses bisnis penjualan yang meliputi prosedur pemesanan barang, pembayaran, pengiriman barang dan laporan.

\section{B. Studi Literatur}

Tahapan ini, menyajikan teori-teori yang terkait dengan permasalahan di Miniso dikumpulkan dan dipelajari. Studi literatur akan

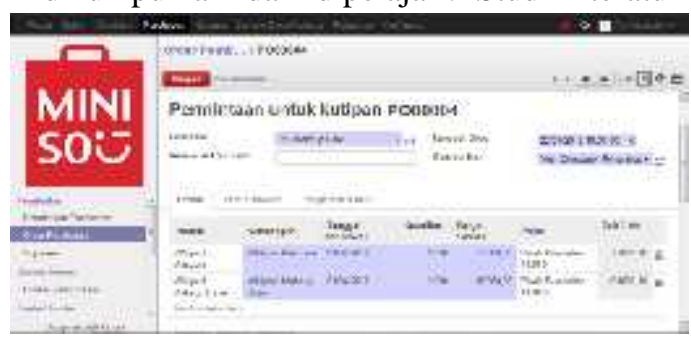

menggambarkan mengenai cara memecahkan masalah dengan tepat dan merumuskan masalah berdasarkan penelitian yang sudah dilakukan sebelumnya. Diharapakan dengan menggunakan aplikasi Odoo ini dapat memberikan keuntungan bagi perusahaan dan memberikan pelayanan yang lebih baik terhadap customer.

\section{Pengumpulan data pada Miniso}

Merupakan tahapan pengumpulan data-data sistem di Miniso dan Software Odoo. Sistem di Miniso meliputi data umum, struktur organisasi, tugas dan wewenang, visi dan misi perusahaan, proses bisnis perusahaan Miniso dan data-data modul dan sub modul software odoo.

\section{Identifikasi Ciri-ciri Software Odoo}

Tahapan ini dilakukan identifikasi pada software odoo yaitu modul-modul yang terdapat pada odoo, fungsi masing-masing modul serta sub modul di setiap modulnya. Identifikasi ini menghasilkan karakteristik software odoo yaitu hubungan antar modul dan sub modul odoo.3.5. Proses Bisnis Perusahaan dan Aplikasi Odoo. [5]

Tahapan ini mengidentifikasi proses bisnis yang dapat dilakukan aplikasi odoo dengan modulmodul dan sub-sub modulnya yang disediakan sesuai dengan proses bisnis perusahaan. Aplikasi ERP lainnya anatara lain ada SAP, Oracle, akan tetapi yang di pilih perusahaan adalah odoo. Setelah aplikasi odoo di pilih, kemudian sistem ERP diterapkan di Miniso. Selanjutnya penerapan ERP diuji dengan membandingkan output yang dihasilkan oleh aplikasi dan hasil yang diingin oleh perusahaan Miniso untuk meningkatkan keuntungan perusahaan dan pelayanan terhadap customer.[6]

\section{E. Perancangan Sistem}

Tahapan ini dilakukan proses addition, elimination, simplification, integration, automation dengan tujuan sistem perusahaan dapat diintegrasikan dengan modul-modul serta sub-sub modul odoo. [7]

\section{F. Hubungan antar Modul dan Sub Modul}

Modul pada software odoo memiliki keterkaitan satu sama lain membentuk suatu hubungan yaitu hubungan modul utama dengan modul pendukung. [8]

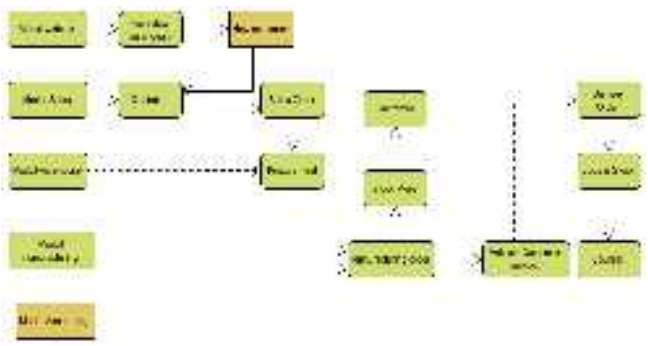


Sumber: Muthiah, Ismah dkk (2018)

Gambar 1.Hubungan modul antar modul dan sub modul

\section{G. Implementasi}

Tahapan ini, dilakukan install database, install modul-modul yang diperlukan sesuai proses bisnis perusahaan, setupuser dan hak akses, dan master data. Setup user disesuaikan dengan rancangan hak akses yang telah dibuat. Master data terdiri atas bill of material, routing, data produk jadi, data produk pemesanan, dan supplier yang selanjutnya di input ke dalam sistem odoo.[9][10]

\section{HASIL DAN PEMBAHASAN}

\section{A. Login User}

Tampilan form login MINISO di aplikasi odoo

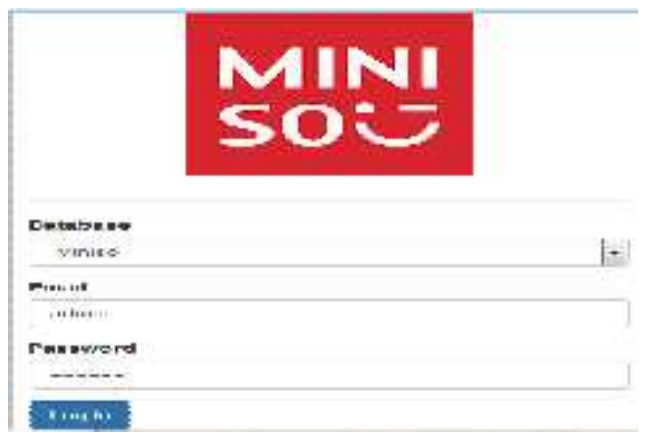

Gambar 2. Login User

\section{B. Navigasi Windows}

Tampilan navigasi MINISO pada aplikasi odoo

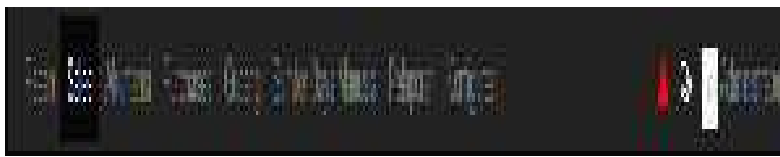

Gambar 3. Tampilan Navigasi Miniso

\section{Modul Warehouse}

1). Tampilan konfigurasi gudang MINISO. Dengan nama gudang MINISO dan lokasi stoknya $\mathrm{WH} /$ popor.
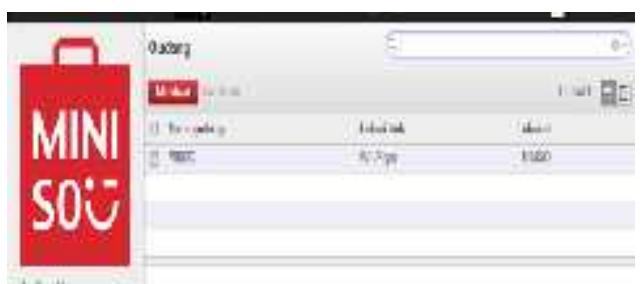

is $x+4$

sit 
Status order pembelian atau permintaan. Permintaan untuk kutipan adalah purchase order status 'Draft'. Kemudian urutan harus dikonfirmasi oleh pengguna. Kemudian supplier harus mengkonfirmasi perintah untuk mengubah status ke telah disetujui.

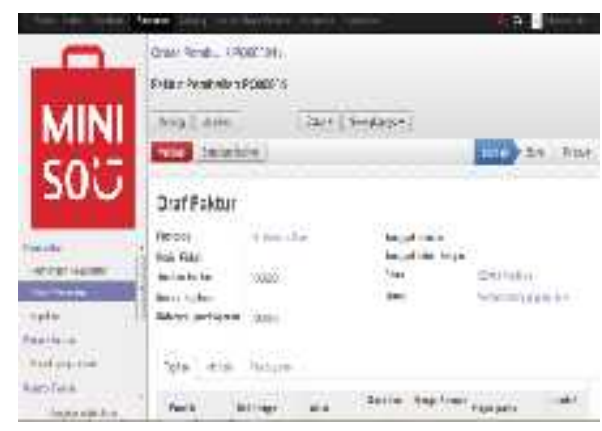

Gambar 8. Faktur penawaran

4). Proses Pembayaran Tagihan PO00004

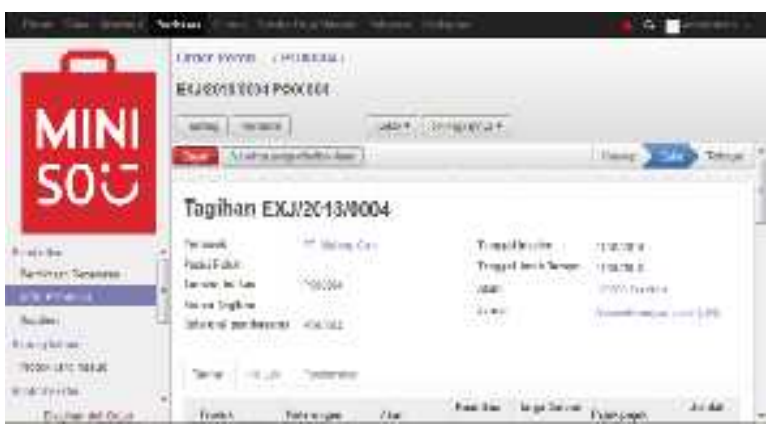

Gambar 9. Pembayran Tagihan

5). Membayar Orderan

Pada pembayaran tagihan PO00004 menggunakan metode pembayaran Cash (IDR)

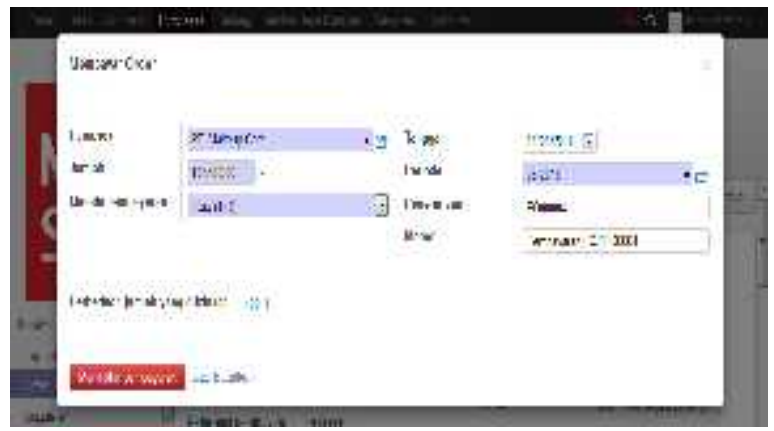

Gambar 10. Pembayran Cash

6). Setelah proses mendaftar pembayaran akan terlihat status terbayar.

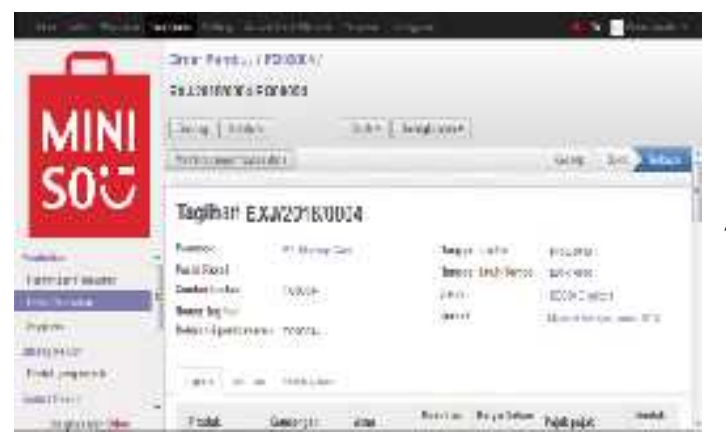

Gambar 11. Pembayaran dengan status terbayar

7). HRM
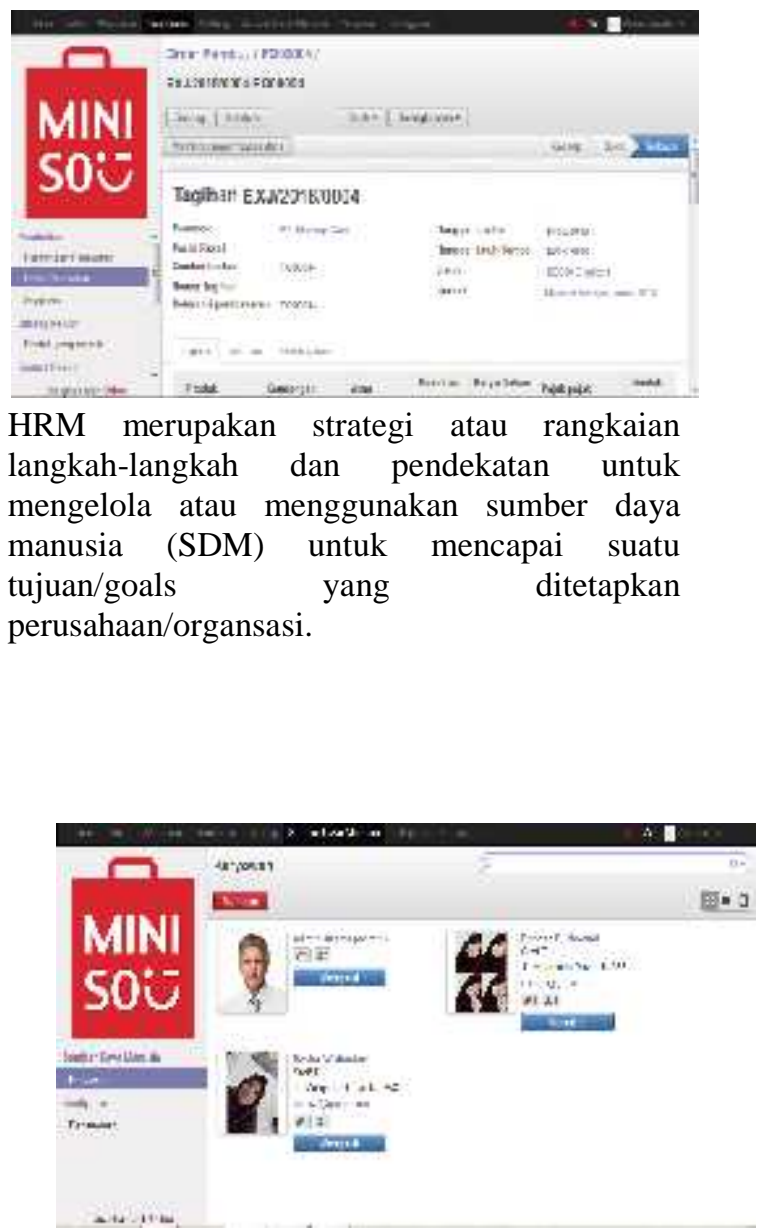

Gambar. 12. Team sumber daya manusia

E. Modul akuntansi

Modul ini terdapat beberapa transaksi di MINISO dari mulai customer sampai ke pemasok atau supplier.

1). Tagihan pembayaran pada customer

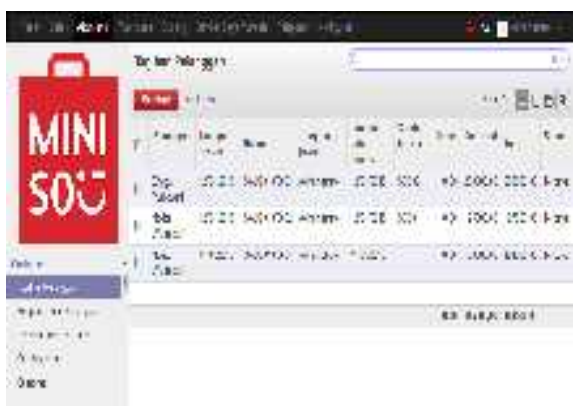


Gambar 13. Tagihan pembayran customer

2). Report/Laporan

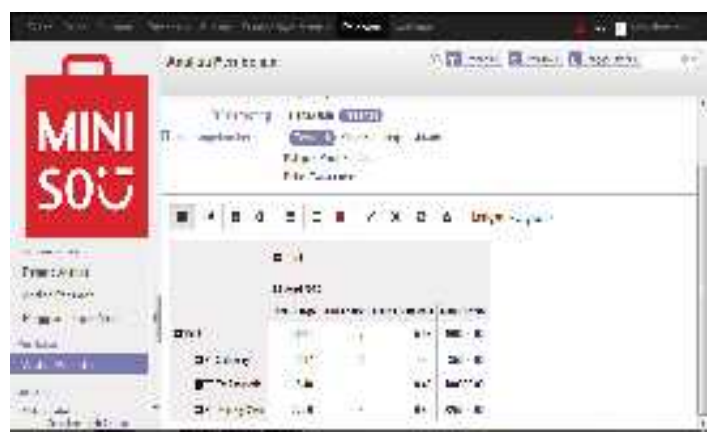

Gambar 14. Laporan

\section{KESIMPULAN}

Berdasarkan pembahasan diatas, maka dapat menyimpulkan beberapa hal sebagai berikut:

1. Odoo merupakan salah satu aplikasiopen source ERP berbasis web yang dapat digunakan sebagai aplikasi Sistem Informasi pengolahan trnasaksi bisnis.

2. Penerapan Odoo yang berbasis web dengan menggunakan modul-modul yang telah disediakan untuk penjualan aksesoris di Miniso ini diterapkan untuk memudahkan menyesaikan permasalahan pada pengolahan data transaksi bisnis dan dan memudahkan user terutama admin untuk mengelola proses transaksi bisnis serta berbagai laporan.

3. Implementasi ERP dapat tiga realisasi antara lain manfaat bisnis, teknologi, dan organisasi. Hal ini didasarkan pada 3 sudut pandang dalam implementasi ERP yaitu sudut pandang bisnis, sudut pandang teknologi, dan sudut pandang organisasi. Dari ketiga realisasi tersebut yang paling dirasakan manfaatnya oleh Miniso adalah dari sisi teknologi, hal terbukti bahwa dapat membantu user dalam pengolahan data transaksi bisnis mulai dari pengadaan barang dari suplier sampai penjualan serta laporan penjualannya.

\section{REFERENSI}

R. Akbar et al., "implementasi enterprise resources planning ( erp ) untuk sistem informasi pembelian, penjualan dan persediaan obat pada apotek sentral herbal jaya padang," j. Teknoif, vol. 3, no. 2, pp. 29-40, 2015.
A. Nofriandi and H. Kamil, "Penerapan Enterprise Resource Planning ( ERP ) pada Sistem Pembelian, Penjualan dan Inventory Barang di Mini Market 7 Putra," vol. 1 , no. 1.

Y. Indanea, R. R. Saedudin, and R. W. Witjaksono, "implementasi sistem produksi berbasis odoo pada pt . Primarindo asia infrastructure tbk dengan metodologi asap implementation of odoo - based production system with asap methodology at pt . Primarindo asia infrastructure tbk," proceeding eng., vol. 3, no. 2, pp. 31953201, 2016.

[4] f. Amri, e. S. Astuti, and riyadi, "analisis implementasi sistem erp (enterprise resource planning) (studi pada pt. Jepe press media utama surabaya)," $j . A d m$. Bisnis, vol. 2, no. 2, pp. 102-109, 2013.

[5] andi, implementasi aplikasi odoo berbasis web. Bandung: informatika, 2014.

[6] y. Defrizal, "penerapan konsep erp pada aplikasi keluhan user bagian helpdesk (studi kasus: pt.sarijaya permana sekuritas)," 2010.

[7] g. P. L. J. Noviana bana f, rispianda, "rancangan implementasi enterprise resource planning berbasis open source menggunakan software odoo pada lini bisnis modul surya di perusahaan elektronika," j. Online inst. Teknol. Nas., vol. 4, no. 1, pp. 158-169, 2016.

[8] f. Q. Arifah et al., "pengaruh visual merchandising terhadap impulse buying ( pada konsumen miniso kota bandung )," pp. 109-123.

[9] d. A. S. Parawansa, a. R. Munir, m. Fakultas, and e. Universitas, "pengaruh visual merchandising, display product, 
dan store atmosphere terhadap perilaku impulse buying ( studi kasus: konsumen matahari department store di kota makassar ) the effect of visual merchandising, product display dan store atmosphere on impulse buying behavior ( case study on matahari department store in makassar city ),” pp. 88-103.

[10] s. S. Utami, "analisis penerapan enterprise resource planning ( erp ) ( studi pada pt domusindo perdana )," vol. 33, no. 1, pp. 165-170. 